\title{
Renal Handling of Low Molecular Weight Proteins
}

\author{
I. L-CHAIN METABOLISM IN EXPERIMENTAL
}

\author{
RENAL DISEASE
}

\author{
R. Peter Mogielnicki, Thomas A. Waldmann, and Warren Strober \\ From the Immunophysiology Section of the Metabolism Branch, National \\ Cancer Institute, National Institutes of Health, Bethesda, Maryland 20014
}

\begin{abstract}
A B S T R A C T Immunoglobulin L-chain metabolism was studied in normal mice, mice with sodium maleate-induced renal tubular disease but normal glomerular filtration rate (GFR), and mice with both tubular disease and decreased GFR. The proteinuric rate of L-chain was increased twofold in mice with tubular disease alone though there was no alteration in the over-all rate at which L-chain odisappeared from the circulation in these animals. This was in sharp contrast to findings in mice with tubular disease and a decreased glomerular filtration rate in which L-chain disappearance rates were markedly reduced. These findings demonstrate that in the normal state, L-chain and presumably other proteins of similar size pass through the glomerulus and are avidly taken up and catabolized by the convoluted tubular cells. In tubular proteinuric states this linked uptake-catabolic function fails, resulting in elevated urinary excretion but normal serum levels and turnover rates of these proteins. In uremic states with decreased glomerular filtration, less small protein is delivered into the tubular lumen and the processes of excretion and catabolism are reduced. This results in prolongation of the survival of small proteins and explains the elevated serum concentrations of these proteins observed in uremia.
\end{abstract}

\section{INTRODUCTION}

The term "tubular proteinuria" refers to a characteristic pattern of proteins excreted in the urine of patients with disorders of the convoluted tubule of the kidney. Tubular proteinuria differs from the glomerular proteinuria of the nephrotic syndrome in two ways. First, the total urinary protein loss is usually much less in tubular proteinuria than in glomerular proteinuria. Second, and more important, relative excretion of large and small

Received for publication 25 July 1970 and in revised form 19 November 1970. proteins is very different in the two conditions. In glomerular proteinuria, most of the protein appearing in the urine is albumin (mol wt 68,000) and transferrin (mol wt 90,000). In tubular proteinuria, the proteins present in greatest abundance are a heterogenous group of molecules having in common relatively low molecular weight $(<50,000)$ including serum enzymes (1), immunoglobulin light chains (2), and perhaps small protein hormones. As the name implies, tubular proteinuria is observed in a number of conditions sharing acquired damage or hereditary abnormality of the renal tubule. Examples include cystinosis (3), Wilson's disease (4), cadmium poisoning (5), hypokalemic nephropathy (6), acute tubular necrosis (7), renal transplantation (8), Balkan nephropathy (9), and the Fanconi syndrome (10).

In studies using physico-chemical and immunological techniques $(11,12)$ the various components of the tubular proteinuria pattern have been described and identified. These studies have established that nearly all of the proteins appearing in the urine of patients with tubular proteinuria are also present in normal serum. In other investigations total urinary excretion rates and plasma clearances of easily measured low molecular weight proteins have been determined in order to estimate the degree of tubular involvement in renal disease $(1,13,14)$. From these studies the concept has evolved that tubular proteinuria results from defective reabsorption of protein by the renal tubular epithelial cell.

The current study was designed to shed additional light on the nature of the renal defect in tubular proteinuria. An experimental Fanconi syndrome was produced in mice using the tubular toxin, sodium maleate. The metabolic fate of a representative small protein, immunoglobulin L-chain, was then studied. The results indicate that tubular proteinuria is due to a failure of both tubular uptake and tubular catabolism of small proteins normally appearing in the glomerular filtrate. 


\section{METHODS \\ Animals}

Male NIH strain mice weighing 20-25 g and maintained on drinking water containing $0.6 \mathrm{~g} /$ liter potassium iodide were used in all experiments.

\section{Preparation of labeled protein}

Immunoglobulin L-chain for turnover experiments was obtained from the urine of female Balb/C mice carrying the RPC-20 mouse myeloma. The protein is well characterized as a single immunological moiety with molecular weight of approximately 24,000 which occurs primarily in the monomeric state (15). Urine collected from these mice was dialyzed against $0.5 \mathrm{M}$ Tris-acetate buffer ( $\mathrm{pH}$ 5.4) and then chromatographed on diethyaminoethyl (DEAE)-cellulose equilibrated with the same buffer. The early protein peak eluted from the DEAE column contained only L-chain as determined by Ouchterlony double diffusion with antiwhole mouse, anti-immunoglobulin mix, and anti- $\lambda$ and anti-k $\mathrm{L}$-chain antisera.

Iodination of the purified protein was accomplished with ${ }^{181}$ I or ${ }^{20} \mathrm{I}$ (Squibb) using the iodine monochloride technique of $\mathrm{McF}$ arlane (16). There were from 0.3 to 1.0 moles of iodine per mole of protein in the final products. Over $97 \%$ of the radioactivity of all preparations was precipitable with $10 \%$ trichloroacetic acid (TCA).

\section{Sodium maleate preparation and administration}

Maleic acid was dissolved in distilled water, neutralized to $\mathrm{pH} 7.0$ with $10 \mathrm{~N} \mathrm{NaOH}$, and brought to a final concentration of either $100 \mathrm{mg} / \mathrm{cc}$ or $50 \mathrm{mg} / \mathrm{cc}$. It was administered intravenously by tail vein at doses of either 200 or $400 \mathrm{mg} / \mathrm{kg}$.

\section{Method of measuring protein metabolism}

The metabolism of labeled L-chain was studied by determining its fractional metabolic rate (per cent of the intravenous pool of $\mathrm{L}$-chain lost per hour to proteinuria and endogenous catabolism), fractional catabolic rate (per cent of the intravenous pool lost per hour to endogenous catabolism alone), and fractional proteinuric rate (per cent of the intravenous pool lost per hour to proteinuria alone). These parameters were determined from serum turnover studies and studies of proteinuria.

Serum turnover studies. Metabolism of labeled L-chain was studied by measuring the rate of disappearance of protein-bound radioactivity from the serum. Animals sacrificed at appropriate intervals after intravenous injection of labeled of concentration of precipitable label at zero time. The concentration of precipitable label at zero time was obtained by dividing the total number of injected counts by the initial volume of distribution, i.e., the plasma volume determined in separate control or appropriately treated animals using iodine-labeled albumin. From the serum die-away curve so obtained the intravenous fractional metabolic rate (per cent of the intravenous pool of L-chain lost to proteinuria or catabolism) was calculated by fitting the data to sums of exponentials with the SAAM-25 program of Berman and Weiss (17). This program was used to calculate fractional metabolic rates by the method of Matthews (18) and Nosslin (19) from curves fit to data points by the least squares method.

Whole body turnover studies. Metabolism of labeled Lchain in these studies was determined as described previously (20) by measuring the rate of decline in proteinbound ( $10 \%$ TCA precipitable) radioactivity of the whole body after intravenous injection of labeled protein. In brief, this was done by measuring the protein-bound activity of aliquots of whole homogenized animals sacrificed at appropriate intervals. The fraction of the initial radioactivity remaining protein bound was considered to be the fraction of injected protein not yet metabolized. The fraction remaining protein bound at each time point was plotted on semilog paper to obtain a whole body die-away curve. Whole body fractional metabolic rates were calculated from these plots by the method of Matthews (18).

Determination of proteinuric rate. The proteinuric rate is here defined as the fraction of the intravenous pool which appears in the urine as intact protein per unit time. This was measured by injecting labeled $\mathrm{L}$-chain intravenously into control and sodium maleate-treated mice and scrupulously collecting urine over the subsequent $3 \mathrm{hr}$. During this period, the animals were anesthetized with $0.25 \mathrm{cc} 3 \%$ chloral hydrate. At the end of the collection period, the animals' bladders were completely emptied by digital compression, the urine added to the $3 \mathrm{hr}$ collection, and the animals sacrificed with ether. Immediately after initial injection and again immediately after sacrifice the number of counts per animal was determined in a Baird-Atomic whole animal gamma counter to determine the number of counts excreted during the study period. After counting, the animals were homogenized, and aliquots of whole homogenate and supernatants of TCA-precipitated homogenate were counted to determine the ratio of bound to free iodide remaining in the animal. The ratio of precipitable to total counts in the $3 \mathrm{hr}$ urine collection was also determined by precipitation with $10 \%$ TCA.

The percentage of over-all metabolism resulting from proteinuria was calculated from the data so obtained as follows :

$$
\text { Per cent metabolism due to proteinuria }=\frac{\text { No. of counts excreted as protein in } 3 \mathrm{hr}}{\text { Total no. of counts lost in } 3 \mathrm{hr} \text { to proteinuria and catabolism }} \times 100
$$

or

$$
\text { Per cent metabolism due to proteinuria }=\frac{\frac{U P C}{U T C}\left(T^{0} C-T^{s} C\right)}{\frac{U P C}{U T C}\left(T^{0} C-T^{8} C\right)+\frac{U N P C}{U T C}\left(T^{0} C-T^{s} C\right)+\frac{H^{8} P C}{H^{*} C}\left(T^{s} C\right)} \times 100
$$

protein were decapitated and bled; the blood was heparinized, spun, and the concentration of protein-bound counts contained in the resultant plasma was determined by precipitation with $10 \%$ TCA. This was expressed as a per cent where $\mathrm{UPC}=$ precipitable counts in urine; $\mathrm{UNPC}=$ nonprecipitable counts in urine; UTC $=$ total counts in urine (UPC + UNPC) ; HNPC = nonprecipitable counts in whole animal homogenate; HTC $=$ total counts in whole animal 
TABLE I

Effect of Sodium Maleate on Renal Function

\begin{tabular}{|c|c|c|c|c|c|}
\hline & $\begin{array}{l}\text { Creatinine } \\
\text { clearance* }\end{array}$ & $\begin{array}{c}\text { Urine } \\
\text { phosphate }\end{array}$ & $\begin{array}{c}\text { Urine } \\
\alpha \text {-amino-N }\end{array}$ & $\begin{array}{l}\text { Urine } \\
\text { glucose }\end{array}$ & $\begin{array}{l}\text { Tubular pattern on } \\
\text { acrylamide-gel } \\
\text { electrophoresis }\end{array}$ \\
\hline & $m l / m i n$ & $m g / 100 m l$ & $m g / l i t e r$ & $\mathrm{mg} / 100 \mathrm{ml}$ & \\
\hline $\begin{array}{l}\text { Control group (5) } \\
200 \mathrm{mg} / \mathrm{kg} \text { maleate }\end{array}$ & $0.136 \pm 0.02$ & 82 & 210 & 460 & - \\
\hline group (5) & $0.168 \pm 0.11$ & 150 & 294 & 2150 & + \\
\hline $\begin{array}{l}400 \mathrm{mg} / \mathrm{kg} \text { maleate } \\
\text { group (5) }\end{array}$ & $0.027 \pm 0.01$ & 270 & 520 & 1250 & + \\
\hline
\end{tabular}

* Creatinine clearances of control and $200 \mathrm{mg} / \mathrm{kg}$ maleate groups not significantly different $(P>0.20)$.

Creatinine clearances of control and $400 \mathrm{mg} / \mathrm{kg}$ maleate groups significantly different $(P<0.001)$.

$\ddagger$ Numbers in parentheses refer to number of animals studied.

homogenate; $\mathrm{T}^{\circ} \mathrm{C}=$ counts in intact animal at onset of experiment; and $\mathrm{T}^{\mathrm{s}} \mathrm{C}=$ counts in intact animal at time of sacrifice.

The per cent of metabolism resulting from proteinuria calculated in this way was then multiplied by the intravenous fractional metabolic rate obtained from turnover studies to obtain the intravenous fractional proteinuric rate or the fraction of the intravenous pool of L-chain excreted each hour as proteinuria.

\section{Operative procedures}

Mice were anesthetized with $3 \%$ chloral hydrate intraperitoneally and ether. Ureters were severed through an abdominal approach. The abdominal wounds were closed with 4-0 Dermalon sutures and sealed with flexible collodion. The radioactivity in the animals as measured with a whole animal counter was the same at the beginning and end of the experiments confirming that the closures of the abdominal wounds were adequate to prevent loss of radioactivity from the abdominal cavity.

\section{Reticuloendothelial blockade and heat-denatured albumin turnovers}

To test the quality of the L-chain preparation, turnovers identical with those described above were done in mice whose reticuloendothelial (RE) systems had been blocked with carbon particles. Blockade was accomplished by intravenous injection of $0.12 \mathrm{cc}$ of "Pelikon" ink (C11/1431 a; Gunther-Wagner, Hanover, Germany) which had been dialyzed overnight against $0.15 \mathrm{M} \mathrm{NaCl}$. The ink was injected $1 \mathrm{hr}$ before injecting labeled proteins. The turnover of ${ }^{131} \mathrm{I}$ labeled heat-denatured albumin was studied simultaneously to verify the presence of $R E$ blockade.

To test the effect of sodium maleate upon the RE system, the turnover of ${ }^{131}$ I-labeled heat-denatured albumin was studied in mice which had received $400 \mathrm{mg} / \mathrm{kg}$ sodium maleate $1 \mathrm{hr}$ previously. Turnovers were done in an identical fashion as those using ${ }^{181}$ I-labeled L-chain.

\section{Documentation of renal tubular defect}

Unconcentrated pooled urines of control and treated mice were examined by acrylamide-gel electrophoresis. Glycosuria was measured by the total reducing substance method of Hofmann (21), phosphaturia was measured by Technicon
AutoAnalyzer, and urinary alpha amino nitrogen was measured by the technique of Clayton and Steele (22).

\section{Measurement of creatinine clearance}

Mice were anesthesized with intraperitoneal $3 \%$ chloral hydrate, and their bladders were emptied by suprapubic pressure. Urine was collected over the subsequent $3 \mathrm{hr}$ at which time bladders were again emptied and the mice decapitated and bled. Serum and urine creatinines were measured by a modification of the Hach method (23).

\section{RESULTS}

Effect of sodium maleate on renal function and histology. As shown in Table I, both $200 \mathrm{mg} / \mathrm{kg}$ and 400 $\mathrm{mg} / \mathrm{kg}$ sodium maleate administered intravenously to mice resulted in phosphaturia, glucosuria, and amino aciduria within $1 \mathrm{hr}$. In addition, on acrylamide-gel electrophoresis, urine of treated animals developed the multiple band pattern similar to that seen in tubular proteinuric patients, while urine from control animals developed only three major bands. No change in creatinine clearance was observed with $200 \mathrm{mg} / \mathrm{kg}$ but a dramatic fall occurred using the $400 \mathrm{mg} / \mathrm{kg}$ dose.

The histologic effects of sodium maleate are shown in Fig. 1. In animals receiving $200 \mathrm{mg} / \mathrm{kg}$, convoluted renal tubular cells were somewhat granular and demonstrated some blunting of the brush border. In animals receiving $400 \mathrm{mg} / \mathrm{kg}$ the convoluted tubular epithelium appeared necrotic with loss of cellular detail. In some places the epithelium had sloughed entirely leaving denuded basement membrane. Some tubular lumina were seen to be plugged with cellular debris. Glomeruli and collecting ducts appeared normal at both maleate doses.

Effect of sodium maleate on L-chain turnover. Fig. 2 shows intravenous disappearance curves for L-chain in controls and in animals receiving $200 \mathrm{mg} / \mathrm{kg}$ sodium maleate-a dose which did not cause any alteration in glomerular filtration rate as measured by creatinine clearance. The curves appear similar and the fractional 

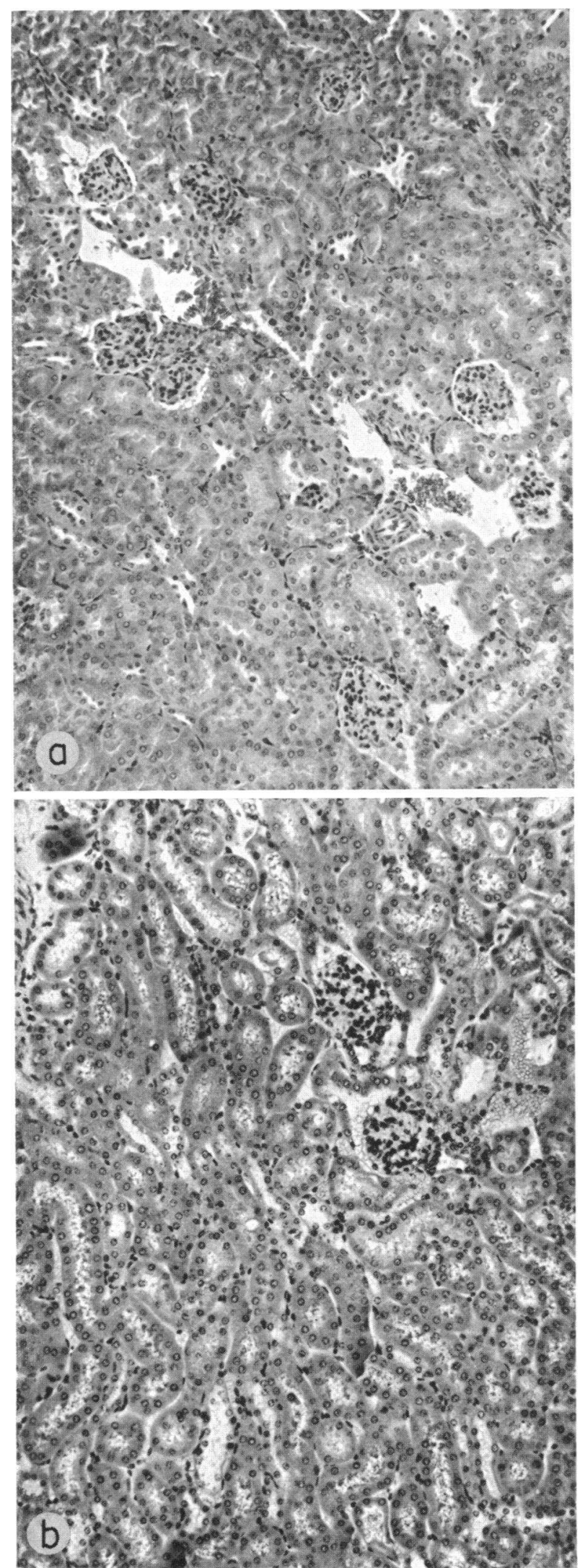

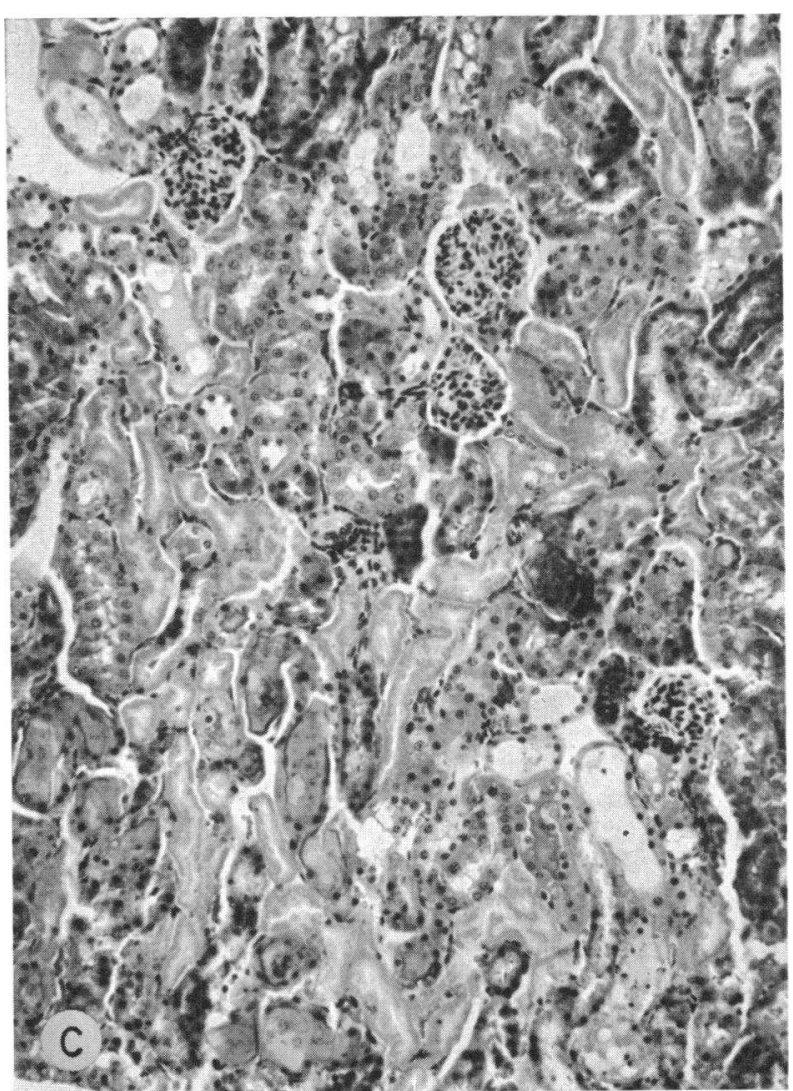

FIGURE 1 Sodium maleate-induced morphologic changes in mouse kidney. Histologic sections (hematoxylin-eosin stain) of kidneys from control mice $(a)$ and from mice which received $200 \mathrm{mg} / \mathrm{kg}(b)$ and $400 \mathrm{mg} / \mathrm{kg}$ (c) sodium maleate $4 \mathrm{hr}$ before sacrifice. $\times 155$. 
TABLE II

Effect of Sodium Maleate on L-Chain Metabolism

\begin{tabular}{|c|c|c|c|c|}
\hline & $\begin{array}{l}\text { Fractional } \\
\text { metabolic } \\
\text { rate } \\
\text { A }\end{array}$ & $\begin{array}{c}\text { Per cent of over-all } \\
\text { metabolism } \\
\text { resulting from } \\
\text { proteinuria* } \\
\text { B }\end{array}$ & $\begin{array}{l}\text { Fractional } \\
\text { proteinuric } \\
\text { rate } \\
\text { C } \ddagger\end{array}$ & $\begin{array}{l}\text { Endogenous } \\
\text { fractional } \\
\text { catabolic } \\
\text { rate } \\
\text { D\& }\end{array}$ \\
\hline & \% i.v. pool $/ h r^{*}$ & $\%$ & $\%$ i.v. pool/hr & $\%$ i.v. pool/hr \\
\hline Control & $70 \pm 5.3$ & $13.1 \pm 2.3$ & 9.2 & 60.8 \\
\hline $200 \mathrm{mg} / \mathrm{kg}$ maleate group & $74 \pm 4.2$ & $25.6 \pm 1.4$ & 18.9 & 55.1 \\
\hline $400 \mathrm{mg} / \mathrm{kg}$ maleate group & $15 \pm 9.5$ & $23.7 \pm 6.3$ & 3.5 & 11.5 \\
\hline
\end{tabular}

* Fractional metabolic rates of control and $200 \mathrm{mg} / \mathrm{kg}$ maleate group not significantly different $(P>0.65)$; per cent of over all metabolism resulting from proteinuria of control and $200 \mathrm{mg} / \mathrm{kg}$ maleate group significantly different $(P<0.01)$.

$\ddagger \mathrm{C}=\mathrm{A} \times \mathrm{B}$.

$\S \mathrm{D}=\mathrm{A}-(\mathrm{A} \times \mathrm{B})$.

metabolic rates (fraction of the intravascular pool lost either to catabolism or by excretion as intact protein per hour) calculated from them (Table II) are statistically identical $(P>0.65), 70 \% \pm 5.3 \%$ for controls and $74 \pm 4.2 \%$ for maleate-treated animals. Hence, damage to the renal tubule in the presence of normal GFR does not alter the rate at which $\mathrm{L}$-chain disappears from the circulation.

Fig. 2 also shows the intravenous disappearance curve in animals treated with $400 \mathrm{mg} / \mathrm{kg}$ sodium maleate. This dose not only causes a Fanconi syndrome and a tubular proteinuria pattern on acrylamide gel, but also lowers creatinine clearance fivefold. The fractional metabolic rate of L-chain in animals so treated is markedly reduced, falling to $14.8 \pm 9.5 \%$ of the intravenous pool per hour.

As anticipated from the intravenous turnovers, sodium maleate at $200 \mathrm{mg} / \mathrm{kg}$ had no effect on the rate of disappearance of $\mathrm{L}$-chain from the whole animal. As shown in Fig. 3 the whole body die-away curves of L-chain are identical in treated and untreated animals.

Effect of sodium maleate on proteinuric rate. As shown in Table II $13.1 \%$ of the over-all metabolism of L-chain was attributable to intact proteinuria in controls, while $25.6 \%$ of this over-all metabolism was attributable to proteinuria in animals receiving $200 \mathrm{mg} / \mathrm{kg}$ of sodium maleate; these values are significantly different $(P<0.01)$. From these values one may derive the fact that control mice excreted $9.2 \%$ of their intravascular L-chain per hour in the form of intact protein, whereas sodium maleate-treated mice excreted $18.9 \%$ of their intravascular L-chain per hour. This constitutes a greater than twofold increase in the proteinuric rate for the experimental group treated with $200 \mathrm{mg} / \mathrm{kg}$ of sodium maleate. It should be noted that a similar percentage of the over-all metabolic rate was attributable to proteinuria in the group of mice with mixed renal disease treated with $400 \mathrm{mg} / \mathrm{kg}$ of sodium maleate. In this case, however, owing to the fact that the over-all metabolic rate was greatly reduced, the proteinuric rate was also reduced.

Effect of sodium maleate on ureter-severed mice. To demonstrate the effect of sodium maleate on catabolism alone (i.e. to exclude the contribution of proteinuria to the over-all metabolic rate), metabolic studies were done in ureter-severed animals. Fig. 4 shows the rate of decline of protein-bound radioactivity in the whole body

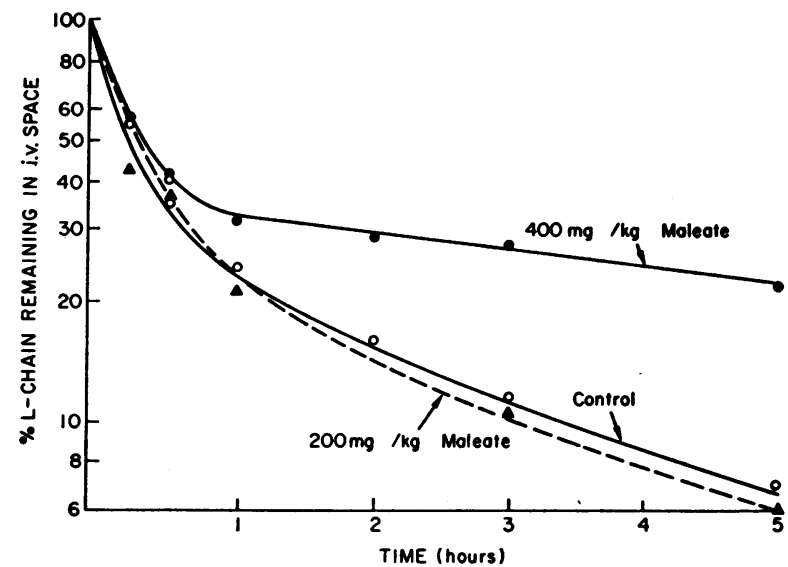

FIGURE 2 Intravenous disappearance curves for L-chain in controls ( $\mathrm{O}-\mathrm{O}$ ) and mice receiving $200 \mathrm{mg} / \mathrm{kg}$ ( $\Delta-\Delta$ ) and $400 \mathrm{mg} / \mathrm{kg}$ (๑- ) sodium maleate. Each point represents the mean value of three to six animals. Curves were fit to points by computer using the least squares method. Fractional metabolic rates (Table II) were calculated from these curves by use of the SAAM 25 program of Berman and Weiss (17) and their standard deviations are a function of both the variance of individual data points and the degree of goodness of fit obtainable with these points. 


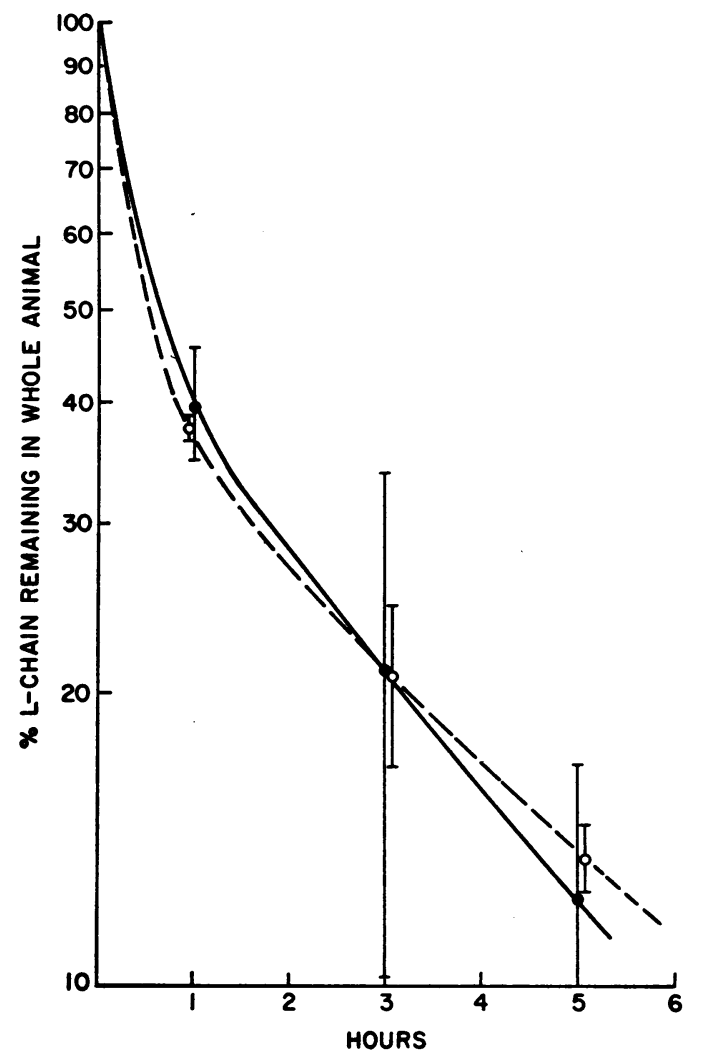

Figure 3 Whole body disappearance curves in control mice (-๑) and mice receiving $200 \mathrm{mg} / \mathrm{kg}\left(\mathrm{O}_{-}-\mathrm{O}^{-}\right)$ sodium maleate daily. Standard deviations of individual data points are shown. Curves are fit visually.

after administration of labeled L-chain to controls and ureter-severed mice that had been treated with 200 $\mathrm{mg} / \mathrm{kg}$ sodium maleate. As was anticipated from the different proteinuric rates in unoperated treated and unoperated control animals, the turnover of L-chain in the maleate-treated, ureter-severed animals was considerably slower than in untreated, ureter-severed controls. The whole body fractional metabolic rate (fraction of whole body L-chain metabolized per hour) for the former was $6.4 \% / \mathrm{hr}$, the latter $21.0 \% / \mathrm{hr}$. These figures cannot be directly related to data obtained in unoperated animals since operation itself probably alters GFR to some extent. They demonstrate quite clearly, however, that sodium maleate decreases L-chain fractional metabolic rate when the effect on endogenous catabolism is not counterbalanced by the effect on proteinuria.

Turnover of heat-denatured albumin and L-chain in RE-blocked and treated animals. Mice in which the reticuloendothelial system had been blocked with carbon particles were found to contain $85.9 \pm 1.5 \%$ of the administered ${ }^{181} \mathrm{I}$-labeled heat-aggregated albumin as intact protein after $5 \mathrm{hr}$, as compared to only $23.6 \pm 7.0 \%$ in control animals confirming that RE blockade had been accomplished. However, L-chain turnover was the same in animals undergoing reticuloendothelial blockade with carbon particles as in normal unblockaded animals. This shows that the effects of sodium maleate are not due to the presence of denatured L-chain in our preparations. Furthermore, the turnover of heat-denatured albumin was not affected by $400 \mathrm{mg} / \mathrm{kg}$ sodium maleate, indicating that even at high doses sodium maleate does not interfere with reticuloendothelial clearance of denatured protein.

\section{DISCUSSION}

In order to study the origin of tubular proteinuria and the role of the kidney in the metabolism of low molecular weight serum proteins, we sought an animal model of renal disease specifically affecting the renal tubule. Animals treated with the appropriate dose of sodium maleate appear to represent such a model. Other investigators have shown that this organic salt is a nephrotoxic agent whose primary histologic and physiologic effects are on the convoluted tubule (24-27). In the present investigation mice receiving $200 \mathrm{mg} / \mathrm{kg}$ of sodium maleate developed the characteristic urinary abnormalities of tubular disease, a Fanconi syndrome with glycosuria, aminoaciduria, and phosphaturia, but showed no change in glomerular function as manifested by normal creatinine clearances. Histologic examination of the kidneys of these mice disclosed flattened brush borders, lumenal vacuolation, and thickened tubular basement membranes, but no changes in the glomeruli or collecting ducts; similar histologic observations have been made by Worthen in rats (28). In contrast, mice treated with $400 \mathrm{mg} / \mathrm{kg}$ of sodium maleate developed a Fanconi syndrome but, in addition, creatinine clearances were decreased. The kidneys of these animals

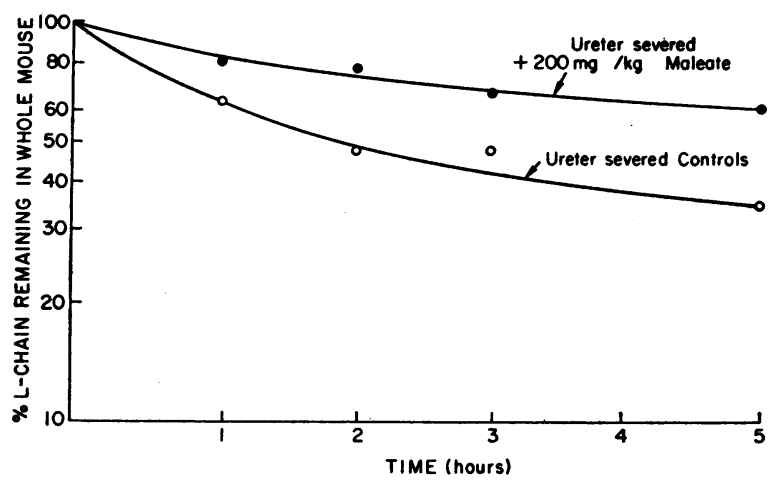

FIGURE 4 Whole body decline in protein-bound radioactivity in ureter-severed controls and ureter-severed mice that had received $200 \mathrm{mg} / \mathrm{kg}$ sodium maleate. 
show considerable disruption of renal architecture with necrosis and sloughing of tubular cells and lumenal plugging with cellular debris. Hence, animals treated with this dose of sodium maleate have a mixed renal disease with alterations of both tubular and glomerular function.

In our metabolic studies in mice with experimental Fanconi syndrome and normal glomerular filtration rate the intravenous fractional metabolic rate for L-chain (the per cent of the intravenous pool of L-chain disappearing due to loss and/or catabolism per unit time) was normal. However, the proteinuric rate in these animals with tubular damage was significantly increased. This normal metabolic rate was, however, accompanied by an increased intravenous fractional proteinuric rate (per cent of the intravenous pool lost as intact protein into the urine per unit time). In contrast, in mice with both Fanconi syndrome and decreased glomerular filtration rate the L-chain intravenous fractional metabolic rate was greatly decreased.

These results offer additional insight into the nature of the renal handling of circulating proteins. Oliver, MacDowell, and Lee (29) showed many years ago that hemoglobin and other proteins appear in renal tubular cells after intravenous injection. Later, Lathem, Davis, Zweig, and Dew (30), by use of stop-flow analysis, were able to demonstrate directly that hemoglobin can be taken up from the proximal tubular lumen. Events following the uptake process were studied by Straus (31), Miller and Palade (32), and Maunsbach (33) who demonstrated with histologic techniques that certain intravenously injected proteins are taken up into renal tubular cells from the lumenal side and then become associated with intracellular digestive bodies, at which time they are at least partially catabolized. The physiologic importance of this renal catabolic mechanism became more evident in the studies of Solomon, Waldmann, Fahey, and McFarlane (34) in uremic patients and by Wochner, Strober, and Waldmann (20) in nephrectomized mice; in these studies renal catabolism was shown to be a major factor in the metabolism of circulating Lchains. In the present studies we show that disruption of tubular function with sodium maleate does not alter the total metabolic rate for L-chains. If significant intact reabsorption of $\mathrm{L}$-chain through the tubular cell did take place in the normal state, then disruption of tubular function would be expected to cause an increase in total L-chain rate. This would result from the urinary loss of protein in animals with tubular dysfunction which, in normal animals, would be reabsorbed, thus prolonging the protein's survival. The fact that the total metabolic rate was not increased in the animals treated with sodium maleate therefore suggests that there is little or no transport of intact L-chain through the convoluted tubular cells back into the blood stream and that protein once taken up by tubular cells is largely catabolized therein.

The metabolic data reported in these studies allows one to propose certain physiologic models for the way in which L-chains and presumably other low molecular weight proteins are handled by the kidney in normal states, tubular proteinuric states, and in states associated with mixed glomerular-tubular disease. In normal states, small proteins which pass with relative ease through the glomerular filter are, to a large degree, taken up by and catabolized in the tubular cells with the resultant salvage of amino acids. In this situation, only a small amount of protein filtered by the glomerulus appears in the urine.

In tubular proteinuric states with normal glomerular filtration rate, protein filtration continues but the process of uptake and catabolism decreases and much more intact protein appears in the urine. Since protein filtration is unchanged the over-all metabolic rate of the protein remains unchanged: the route of metabolism has merely been shifted from catabolism to proteinuria. Previous studies of tubular proteinuria fit well with this physiologic model. It has been shown that nearly all the proteins of tubular proteinuria originate in the serum and most of them are present in normal urine in minute amounts $(12,35,36)$. In addition, Harrison, Lunt, Scott, and Blainey (1) have shown that patients with abnormal tubular function have high excretion rates of certain small proteins while normal patients have negligible excretion rates of these proteins. It is clear from the present study that such increased excretion rates are not associated with changes in the clearance of protein if one thinks of clearance as a measure of the rate of removal of a substance from the blood. In tubular proteinuria, the clearance of protein from the blood is unchanged but the pathway of removal is shifted from tubular uptake and catabolism to urinary excretion.

In conditions associated with uremia and profoundly decreased glomerular filtration rates as in the case of the group of animals treated with $400 \mathrm{mg} / \mathrm{kg}$ of sodium maleate, less protein finds its way into the tubular lumen to be delivered to the catabolic machinery or excreted and hence a decline in the metabolic rate is seen similar to that observed in complete nephrectomy. This loss of both catabolic and excretory function in states of decreased glomerular filtration explains the high serum levels and prolonged survivals of certain small proteins seen in uremia (37-39). In diseases in which there is a mixture of both tubular and glomerular disease, one may predict that the accumulation of low molecular weight proteins in the serum will be proportional to the magnitude of the glomerular component of the disease.

In other studies performed in this laboratory the 
mechanism of the renal handling of L-chains described in this paper has been shown to apply to a number of other small proteins. These low molecular weight serum proteins include a number of hormones and enzymes such as ribonuclease and lysozyme and therefore are molecules of considerable biologic activity. The accumulation of such proteins in the circulation due to decreased renal catabolism or excretion may be the cause of some of the poorly understood manifestations of uremia.

Renal tubular uptake and catabolism may also apply to proteins of higher molecular weight such as albumin. However, this would depend on the extent to which such proteins can gain access to the tubular lumen. In the normal animal with a normal glomerular basement membrane no significant renal catabolism of albumin occurs. However in both clinical and experimental nephrotic syndrome, wherein there is a significant passage of albumin across the glomerular basement membrane, one does indeed see an increased rate of endogenous albumin catabolism presumably due to uptake and catabolism of this protein in renal tubular cells $(40,41)$.

\section{ACKNOWLEDGMENTS}

We wish to thank Dr. Robert McIntyre for providing the RPC-20 myeloma and Miss Nancy Poffenberger for her enthusiastic technical assistance.

\section{REFERENCES}

1. Harrison, J. F., G. S. Lunt, P. Scott, and J. D. Blainey. 1968. Urinary lysozyme, ribonuclease and low-molecularweight protein in renal disease. Lancet. 1: 371.

2. Waldmann, T. A., and W. Strober. 1969. Metabolism of immunoglobulins. Progr. Allergy. 13: 1.

3. Butler, E. A., F. V. Flynn, H. Harris, and E. B. Robson. 1961. A study of urine proteins by two-dimensional electrophoresis with special reference to the proteinuria of renal tubular disorders. Clin. Chim. Acta. 7: 34.

4. Berggard, I. 1965. In Protides of the Biological Fluids. H. Peeters, editor. Proceedings of the 12th Colloquium, Bruges, 1964. Elsevier. Armsterdam. 285.

5. Piscator, M. 1966. Proteinuria in chronic cadmium poisoning. Arch. Environ. Health. 12: 335.

6. Butler, E. A., and F. V. Flynn. 1961. The occurrence of post-gamma protein in urine: a new protein abnormality. J. Clin. Pathol. 14: 172.

7. Revillard, J. P., and Y. Manuel. Les Protéinuries, valeur séméiologique der leur Etude Electrophorétique. Camugli, Lyon. 1965.

8. Debray-Sachs, M., and C. Sachs. 1966. Proteinuria in patients with homotransplanted kidney. Nature (London). 212: 209.

9. Study Group on the Balkan (or Endemic) Nephropathy, London, 1967. The Balkan Nephropathy. 1967. G. E. W. Wolstenholme and J. Knight, editors. J. \& A. Churchill Ltd., London.

10. Butler, E. A., and F. V. Flynn. 1958. The proteinuria of renal tubular disorders. Lancet. 2: 978.

11. Creeth, J. M., R. A. Kekwick, F. V. Flynn, H. Harris, and E. B. Robson. 1962. An ultracentrifuge study of urine proteins with particular reference to the proteinuria of renal tubular disorders. Clin. Chim. Acta. 8: 406.
12. Flynn, F. V., and H. S. Platt. 1968. The origin of the proteins excreted in tubular proteinuria. Clin. Chim. Acta. 21: 377.

13. Harrison, J. F., and J. D. Blainey. 1967. Low molecular weight proteinuria in chronic renal disease. Clin. Sci. 33: 381 .

14. Schultze, H. E., and J. F. Heremans. 1966. Molecular Biology of Human Proteins with Special Reference to Plasma Proteins. Vol. I. Elsevier, Amsterdam. 696.

15. Kuff, E. L., M. Potter, K. R. McIntire, and N. E. Roberts. 1964. The in vitro synthesis of specific secretory protein by an ascites plasma-cell tumor. Biochemistry. 3: 1707.

16. McFarlane, A. S. 1958. Efficient trace-labelling of proteins with iodine. Nature (London). 182: 53.

17. Berman, M., and M. F. Weiss. 1967. Users Manual for SAAM (Simulation, Analysis and Modeling). U. S. Public Health Service Publication No. 1703. U. S. Government Printing Office, Washington, D. C.

18. Matthews, C. M. E. 1966. Round table on applications of tracer theory to protein turnover studies. In Conference on problems connected with the preparation and use of labeled proteins in tracer studies. J. Nucl. Med. 10: 382 .

19. Nosslin, B. 1966. Round table on applications of tracer theory to protein turnover studies. In Conference on problems connected with the preparation and use of labeled protein in tracer studies. J. Nucl. Med. 10: 379.

20. Wochner, R. D., W. Strober, and T. A. Waldmann. 1967. The role of the kidney in the catabolism of Bence Jones proteins and immunoglobulin fragments. J. Exp. Med. 126: 207.

21. Hoffman, W. S. 1937. A rapid photoelectric method for the determination of glucose in blood and urine. J. Biol. Chem. 120: 51.

22. Clayton, C. C., and B. F. Steele. 1967. A modified copper method for the estimation of $\alpha$-amino nitrogen in urine. Clin. Chim. Acta. 13: 49.

23. Hawk, P. B., B. L. Oser, and W. H. Summerson. 1947. In Practical Physiological Chemistry. The Blakiston Co., Philadelphia. 12th edition. 506.

24. Berliner, R. W., T. J. Kennedy, and J. G. Hilton. 1950. Effect of maleic acid on renal function. Proc. Soc. Exp. Biol. Med. 75: 791.

25. Harrison, H. E., and H. C. Harrison. 1954. Experimental production of renal glycosuria, phosphaturia, and aminoaciduria by injection of maleic acid. Science (Washington). 120: 606.

26. Rosenberg, L. E., and S. Segal. 1964. Maleic acid-induced inhibition of amino acid transport in rat kidney. Biochem. J. $92: 345$.

27. Rogulski, J. 1960. Grupy Sulfhydrylowe Tkanek Szczurow Po Zatruciu kwasem Maleinowyn Acta Biochim. Pol. 7: 239.

28. Worthen, H. G. 1963. Renal toxicity of maleic acid in the rat. Enzymatic and morphologic observations. Lab. Invest. 12: 791.

29. Oliver, J., M. MacDowell, and Y. C. Lee. 1954. Cellular mechanisms of protein metabolism in the nephron. I. The structural aspects of proteinuria; tubular absorption, droplet formation, and the disposal of proteins. J. Exp. Med. 99: 589.

30. Lathem, W., B. B. Davis, P. H. Zweig, and R. Dew. 1960. The demonstration and localization of renal tubular reabsorption of hemoglobin by stop flow analysis. $J$. Clin. Invest. 39: 840. 
31. Straus, W. 1961. Cytochemical observations on the transport of intravenously injected horseradish peroxidase and the development of phagosomes in the cells of the kidney of the rat. Exp. Cell Res. 22: 282.

32. Miller, F., and G. E. Palade. 1964. Lytic activities in renal protein absorption droplets. J. Cell Biol. 23: 519.

33. Maunsbach, A. B. 1966. Absorption of $I^{162}$-labeled homologous albumin by rat kidney proximal tubule cells. A study of microperfused single proximal tubules by electron microscopic autoradiography and histochemistry. J. Ultrastruct. Res. 15: 197.

34. Solomon, A., T. A. Waldmann, J. L. Fahey, and A. S. McFarlane. 1964. Metabolism of Bence Jones proteins. J. Clin. Invest. 43: 103.

35. Harrison, J. F., and B. E. Northam. 1966. Low molecular weight urine protein investigated by gel filtration. Clin. Chim. Acta. 14: 679.
36. Berggård, I. 1961. Studies on the plasma proteins in normal human urine. Clin. Chim. Acta. 6: 413.

37. Houck, J. C., and L. B. Berman. 1958. Serum ribonuclease activity. J. Appl. Physiol. 12: 473.

38. Easterling, R. E. 1970. Serum amylase, lipase, lactic dehydrogenase (LDH), creatine phosphokinase, and glutamic-oxalacetic transaminase (SGOT) in renal failure treated by hemodialysis. Ann. Intern. Med. 72: 804.

39. Berggard, I. 1970. In Proteins in Normal and Pathological Urine. Y. Manuel, editor. University Park Press, Baltimore. 18

40. Gitlin, D., C. A. Janeway, and L. E. Farr. 1956. Studies on the metabolism of plasma proteins in the nephrotic syndrome. I. Albumin, $\gamma$-globulin and iron binding globulin. J. Clin. Invest. 35: 44.

41. Katz, J., A. L. Sellers, and G. Bonorris. 1964. Plasma albumin metabolism during transient renin proteinuria. J. Lab. Clin. Med. 64: 709. 